\title{
Improving the Tariff Policy of Urban Passenger Transport Based on International Experience
}

\author{
Iryna Bashynska \\ Department of Accounting, Analysis and Audit, Odessa National Polytechnic University, \\ 65044 Odessa, Ukraine
}

\begin{abstract}
The article is devoted to the study of theoretical and methodological principles and international experience in the formation of tariffs for passenger traffic. The author considered the theoretical and methodological bases of urban passenger transport and tariff policy in Ukraine and Odesa, investigated foreign practice on tariff and compensation policy in urban passenger transport and suggested ways to improve tariff policy of urban passenger transport.
\end{abstract}

Keywords - municipal enterprise, Odessa, smart city, tariff policy, Ukraine, Urban Passenger Transport (UPT).

\section{Introduction}

Previous author's studies [1], [2] have shown that Ukraine's transport system still has many shortcomings.

Researches of scientists are devoted to different aspects of the functioning of urban passenger transport. Scientists considered technical aspects of transport [5], evaluated the environmental friendliness [8], [11] and the safety of UPT [3], [6].

DOI: $10.18421 /$ TEM94-34

https://doi.org/10.18421/TEM94-34

Corresponding author: Iryna Bashynska, Odessa National Polytechnic University, Ukraine. Email: i.bash@ukr.net

Received: 09 June 2020.

Revised: 28 October 2020.

Accepted: 03 November 2020.

Published: 27 November 2020.

(c) BY-NC-ND (C) 2020 Iryna Bashynska; published by UIKTEN. This work is licensed under the Creative Commons Attribution-NonCommercial-NoDerivs 4.0 License.

The article is published with Open Access at www.temjournal.com
Meanwhile, several studies are devoted to the formation of tariff policy, both its general issues [9] and narrower ones, namely the integrated tariff and ticket system [4]; modeling of tariffs in passenger transport [7], etc.

However, the analysis of the scientific literature showed that in modern conditions the issue of tariff policy of urban passenger transport enterprises is insufficiently disclosed and generalized. Hence, the purpose of the article is to study the theoretical and methodological principles and foreign experience in the formation of tariffs for passenger traffic.

For the purpose of this work we set the following tasks:

- to consider theoretical and methodical bases of urban passenger transport and tariff policy in Ukraine and Odessa;

- to analyze the experience of foreign countries on tariff and compensation policy in urban passenger transport.

\section{Urban Passenger Transport and Tariff Policy in Ukraine and Odessa}

In the context of European integration, Ukraine demands the use of the latest forms and methods of managing the country's economy through the intensification of Ukraine's cooperation with EU countries. This is especially true of the sectors of the national economy that contribute to the European integration processes, which primarily include the transport sector.

One of the main tasks of the city's transport complex development concerning urban passenger transportation is to increase the efficiency of transport enterprises based on the formation of the market of transport services and capital, as well as the creation of a capable and active owner.

Enterprises of all forms of ownership can be involved in the sphere of urban passenger transportation. Exceptions are those areas of activity that are related to the organization of traffic safety and control. These activities should be provided by 
organizational state or communal structures. These structures should also deal with the formation of the route network, traffic schedules, public transport stops, roads, and other elements of the transport infrastructure.

Currently, the following are the participants of the city transport service system in Odessa:

- owners of vehicles;

- drivers;

- customer;

- enterprises;

- carriers.

In order to have a clear understanding of the urgency of the current transport problems of the city, it is necessary to remember that it is a city of millions and requires a precise work of the city transport.

The organizer of transportations is the Management of a transport complex of the city of the Odessa council.

The organization that provides preparation of materials for the meetings of the competition committee - PCF LLC "Electrotransodessa" and the Association of "Odessa Carriers", the main carrier of the city's citizens is CE "Odesmiskelectrotrans".

The customer of transportations is the Odessa city council under the management of a transport complex of the city.

The carrier is an organization in the service of which part of the city routes is transferred. The enterprise can service the roads with its transport, which is on its balance sheet, or involve in the service routes of private entrepreneurs who have their own or leased rolling stock.

When performing passenger transportation on public bus routes of general use, the carrier must provide:

- compliance with the requirements of the Law of Ukraine "On-Road Transport", the Rules for the provision of passenger road transport services and other laws and regulations in the field of passenger transport;

- maintenance of vehicles in a proper technical and sanitary condition;

- advanced training of managers and specialists of road transport, conducting training and instruction of drivers, running their medical control of health;

- the implementation of preferential transportation of passengers who, following the law, have the right to exercise such rights.

Also, during the term of the contract between the transport organizer and the winner of the competition, the route and other characteristics of the route may be changed.
A private entrepreneur, in turn, either performs the duties of a driver or enters into an employment contract with an employee.

In 2019, a network of bus, tram and trolleybus routes was created in the city to meet the needs of the population of Odessa in passenger transportation. The total length of the city's route network is about $3457.4 \mathrm{~km}$. The density of the route network (average total length of all routes passing through the territory with an area of $1 \mathrm{~km}^{2}$ ) is $24.9 \mathrm{~km} / \mathrm{km}^{2}$. This indicator is one of the highest in Ukraine [10].

The route network of the city includes about 204 routes, including 23 tram, 15 trolleybus and 166 bus routes. On all routes of urban electric transport (tram and trolleybus), as well as on about 38 bus routes, transport operates in normal mode. The transport, which operates in the usual way of traffic, carries out the transportation of privileged categories of passengers in full on 128 bus routes, the transport functions in the mode of a route taxi, which carries privileged types of passengers according to the abbreviated list. The total volume of passenger traffic in Odessa is estimated at more than 298.3 million passengers annually [10].

The cost of the fare in trams and trolleybuses of the usual mode of movement is $5 \mathrm{UAH}$. According to the analysis made by the management of the transport complex of the Children's City Council, the average cost of travel in the mode of a minibus, in the buses of the big and average class. With an average route length of $22.6 \mathrm{~km}$, the price of one kilometre in Odessa is 31 kopecks, which is the lowest among the major cities of Ukraine. On city bus routes the zonal cost of travel is fixed if they are used as a route taxi with the great length of a round trip.

At present, there are 25 transport companies (enterprises that serve city routes) in the market of urban passenger transportation in Odessa, and another 14 organizations are registered as enterprises engaged in the transportation of goods.

In general, the level of provision of the population with passenger transportation according to the leading indicators is satisfactory, exceeding the level reached in other cities in Ukraine.

For the past five years, the process of stabilizing the work of urban electric transport has been continuing, and the number of buses operating in normal mode has increased.

Tariff policy is an integral part of the general economic and social policy of the state, which has established free pricing in competitive market sectors. Government and, accordingly, communal tariff regulation extends to the cost of services that have significant social significance, or to services provided by monopoly enterprises.

The social function of public passenger transport the general accessibility of its services to the entire population, requires the preservation of state regulation of fares on socially significant routes. 
Free pricing is based on the routes served by the transport in the "express" and "route taxi" modes.

Tariff policy in Odessa is built following the resolution of the Cabinet of Ministers of Ukraine dated 25.12.96 N 1548 "On establishing the powers of executive bodies and executive bodies of city councils to regulate prices (tariffs)".

Tariffs for passenger transportation in Odessa (except for socially significant transportation) should provide the carrier:

- compensation of reasonable current expenses;

- restoration of rolling stock in the amount of 8$12 \%$ per year;

- ensuring investment attractiveness with the profitability of transportation $-15 \%$.

The unit costs for each carrier should be based on the relevant standards and take into account the following conditions:

- operation of vehicles is carried out at the level of their daily access to the line with a park utilization factor of not less than 0.85 ;

- on the routes should be used vehicles that have the capacity of the appropriate passenger flow;

- unit costs under the main articles should not exceed the relevant standards;

- should not take into account costs not related to transportation.

The city's tariff policy should consist in the maximum maintenance of tariffs for transportation on socially significant routes and influence on pricing on other routes on a competitive basis.

Economic methods of regulating the activity of urban passenger transport should ensure several functions (Fig. 1.).

Ensuring the economic methods of regulating the activity of urban passenger transport

\begin{tabular}{|c|}
\hline $\begin{array}{l}\text { the protection of the economic interests } \\
\text { of consumers of services (passengers) }\end{array}$ \\
\hline $\begin{array}{l}\text { the investment attractiveness of the } \\
\text { urban passenger transport market }\end{array}$ \\
\hline $\begin{array}{l}\text { the protection of the interests of carriers in } \\
\text { the implementation of preferential } \\
\text { transportation and work at regulated rates }\end{array}$ \\
\hline $\begin{array}{l}\text { the investment attractiveness of the urban } \\
\text { passenger transport market }\end{array}$ \\
\hline $\begin{array}{l}\text { the protection of the interests of carriers in } \\
\text { the implementation of preferential } \\
\text { transportation and work at regulated rates }\end{array}$ \\
\hline
\end{tabular}

Figure 1. Economic methods of regulating the activity of urban passenger transport
The economic characteristics of the routes are reflected in the relevant economic passports, which make it possible to complete the appropriate route packages for submission to the tender. One of the most important economic characteristics of the route is its profitability, while the routes operating in different modes of movement differ sharply in this indicator. Large and medium-class buses operating in the minibus mode have profitability of up to $10 \%$, and routes served by small-class buses, as a rule, run with the profitability of more than $25 \%$. Therefore, the investment policy for rolling stock operating on different routes differs significantly.

\section{Study of Foreign Practice on Tariff and Compensation Policy in City Passenger Transport}

To reform the tariff and compensation system in Ukraine it is useful to consider international experience, as it provides an opportunity to find constructive points and effective methods that can be implemented.

Transport policy in many countries around the world is aimed at encouraging more frequent travel by citizens. Particular attention should be paid to the tariff policy of the Transport Center of the Hungarian capital.

Both the development of various tariff plans and the administration of revenues from the sale of travel documents and fines are carried out by the Budapest Municipal Transport Center, not the carrier. Gains from the sale of travel documents are not enough to cover all operating costs. However, the functions of the Transport Center are much broader than those of a regular carrier. Besides, state and municipal subsidies are used, revenues from the sale of advertising space and the use of the real estate, revenues from parking, fees for the issuance of work permits. At the same time, the management of the Center is responsible for the increase of additional payments and revenues from the sale of travel documents due to the introduction of new tariff plans. Funds from the European Union are also involved in development projects.

There are about 50 different tariff plans in Budapest. Also, there are tariffs for river transport and tariff plans, taking into account the suburban area. City tariff plans can be divided into three groups: one-time tickets, travel cards and passes.

In Budapest, there is a single charging system, regardless of the type of transport: metro, tram or trolleybus (Table 1.). Payment is made in local currency - forints; however, for convenience, in individual work, all amounts will be converted into US dollars. 
Table 1. Tariff plans for travel in the city passenger transport of Budapest and their features

\begin{tabular}{|c|c|c|}
\hline 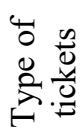 & Features & Tariff plans \\
\hline 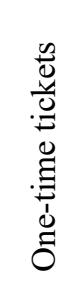 & $\begin{array}{l}\text { Require validation at the } \\
\text { beginning of the trip and } \\
\text { have a validity period } \\
\text { from the moment of } \\
\text { validation. }\end{array}$ & $\begin{array}{l}\text { The ticket costs } \\
1.17 \text { forints. Such } \\
\text { a ticket can be } \\
\text { purchased from } \\
\text { the driver, but then } \\
\text { it will cost } \$ 0.33 \\
\text { more. }\end{array}$ \\
\hline 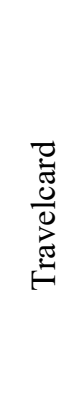 & $\begin{array}{l}\text { This group of travel } \\
\text { documents does not } \\
\text { require validation. They } \\
\text { are not registered, except } \\
\text { for the 7-day card. They } \\
\text { operate, as a rule, for a } \\
\text { certain period and allow } \\
\text { you to make an unlimited } \\
\text { number of trips during } \\
\text { this period. }\end{array}$ & $\begin{array}{l}\text { One-time tickets } \\
\text { can be purchased } \\
\text { in bulk in the } \\
\text { amount of } 10 \text { pcs } \\
\text { at the cost of one } \\
\text { ticket } \$ 1 \\
\text { (discount - } 14 \% \text { ). }\end{array}$ \\
\hline 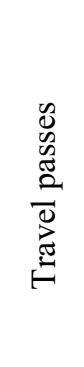 & $\begin{array}{l}\text { In addition to unlimited } \\
\text { use of public transport for } \\
\text { a certain period, the } \\
\text { Budapest Card provides } \\
\text { free (or with discounts) } \\
\text { visits to some tourist } \\
\text { locations, excursions, and } \\
\text { food establishments. }\end{array}$ & $\begin{array}{l}\text { A single ticket } \\
\text { with a transfer } \\
\text { costs } \$ 1.77 \text { and } \\
\text { allows you to } \\
\text { make two } \\
\text { consecutive trips } \\
\text { on the subway and } \\
\text { one land transport } \\
\text { (discount - } 24 \% \text { ). }\end{array}$ \\
\hline
\end{tabular}

Budapest's public transport also offers free travel benefits. They apply to the following categories of passengers:

- preschool children accompanied by an adult (regardless of whether they occupy a separate place in the cabin);

- passengers over 65 years of age (citizens of Hungary, EU countries, the European Economic Area and Switzerland, foreigners receiving an old-age pension from the Hungarian Pension Fund, foreign citizens of Hungarian nationality and others);

- refugees over 65 years of age;

- blind and deaf;

- disabled people;

- one person accompanying a blind, deaf or disabled person;

- war invalids and military widows and others.

Students and full-time students and, in any case, children up to the age of 14 are entitled to student travel.
In the absence of conductors, inland transport and selective control of travel documents, in public transport in Budapest, severe fines are enough. The grounds for the fine may be different: the absence of a ticket valid at the time of the inspection, the lack of an ID or other document confirming the right to benefits, the discrepancy between the ID number and the number specified in the application, etc.

At the same time, the system of fines is very flexible. If the fine is paid on the spot in cash or at a service centre within two days (by card or cash), the amount of the fine is $\$ 2.67$. This is 23 times the cost of a single ticket. If the fine is paid within 30 days (postal or bank transfer, cash, card), the amount of the fine is $\$ 5.34$. This is 46 times the cost of a single ticket. If the fine is paid after 30 days, the fine is $\$$ 10.68. This is 91 times the value of a single ticket. In case of non-payment, this issue is resolved in court, in the future, the right to debt is transferred to a third party.

In the event that a valid pass, ID or a document granting the right of free travel has been forgotten at home, it is possible to show them at the Service Center within 5 days. The fine will be only $\$ 6.68$, and in the case of documents for free travel, annual, semester and quarterly travel - $\$ 3.34$. For those who use free travel, the third fine in a year will cost $\$ 6.68$ instead of $\$ 3.34$.

In Germany, the ticket price, in the case of a large city, depends on that part of the city and the destination. For example, there are three zones in Berlin - A, B and C. Zone A is the Center of the city, zone $\mathrm{B}$ covers the rest of Berlin practically, and zone $\mathrm{C}$ includes the suburbs, which include Schönefeld Airport. Each German city has different tariff zones in terms of number and size.

There are several categories of public transport tickets. Short-distance ticket - in Berlin, for example, operates up to three stops on the $\mathrm{S}$ and U-Bahn or six stops by bus or tram. A ticket for one trip with the possibility of transfers for one or two hours, a ticket for a day, for a week, a month or a year. Besides, there are tickets for a group of up to 4-6 people and tickets for schoolchildren and students. Also, to carry a bike, you need to buy a separate ticket.

Select travel is provided for tourists in some large cities. In Berlin, for example, such a ticket is called Welcome Card, in Hamburg - Hamburg Card. In addition to travel, the tourist receives a catalogue of discounts on sightseeing and a city map. And employees of many German companies have the opportunity to buy a pass for Jobticket - it is more profitable than a regular access because the company assumes part of its value.

The cost of the ticket also depends on the region of Germany. In the same Berlin, the cost of a ticket for one trip is not the highest in the country - from $\$$ 3.11 , depending on the fare zone. The most expensive ticket is in Hamburg - from \$ 3.67, and the cheapest - in Erfurt (from \$2.22). As for tickets per day, some of the most expensive are sold in 
Cologne and Bonn (from \$ 8.1). But in Frankfurt am Main, a day ticket is one of the cheapest in Germany and costs from $\$ 4.55$.

Tickets can be purchased at vending machines that are installed at the stop, next to it or in the tram itself. They are sold by drivers on the bus - and in this case, they are not more expensive. Also, some large stations have information service centres, where you can find out how best to get from point A to point B, which travel category to choose or buy a ticket.

Another option is to purchase online on the Deutsche Bahn website, via the DB Navigator application or the specific transport association (Verkehrsverbund), which is responsible for a particular region of Germany. So it turns out cheaper. In the mobile application, you can also pave the route and see the schedule of public transport.

It is also important not to forget to pack a ticket, otherwise, it will be considered invalid. This is only necessary if the ticket says "Hier entwerten" ("Devalue here").

In Poland, a large number of benefits were provided in the 1990s. Compensation for travel benefits comes from the state and local budgets through the Ministry of Infrastructure and Development. Disabled people, pensioners, children, soldiers, teachers, students have the opportunity to issue a ticket upon presentation of a document certifying the right to benefits. You can get an advantage with an income of less than $\$ 125$ per month. The amount of services depends on the central and local government.

In Bulgaria, compensation is based on an agreement between the state Ministry of Transport and the carrier (for 5 years). The discount ticket is issued upon presentation of a document certifying the person's right to the benefit. Disabled people, war veterans, pensioners, children from 7 to 10 years old, students up to 26 years of age have this right.

In Austria, the tariff is set by the business association, which is approved by the city council. The tariff in Vienna covers $50 \%$ of the cost, in the city - 100\%. Semester tickets for students, compensation for the transportation of schoolchildren and students of technical schools, pensioners (50\%) were introduced.

Lithuania shall reimburse the carrier in full for the intended purpose from the state budget through the Ministry of the Union. Account forms by groups of beneficiaries and routes are compiled every month. Fifteen categories of beneficiaries issue a ticket upon presentation of a document certifying their right to benefits (people with disabilities, war veterans and their families, pensioners, children, etc.). The country has privileged benefits on a professional basis. Free travel to social categories is replaced by trip with a discount $-80,50 \%$ depending on the category of the recipient. Privileges in urban transport are financed by local authorities, and the state budget finances privileges for long-distance transportation.
It is significant that in Western countries, there is a widespread system of the introduction of electronic social cards, thanks to which the automation of benefits is carried out. This allows creating a territorially distributed information system that operates at the state, regional and local levels.

It is also worth considering the experience of providing transport benefits in CIS countries.

In Belarus, since 2007, compensation has been subsidized from the state budget in full. Carried out upon presentation of a document certifying the right to benefits (certificate - suburban connection, certificate and coupon - long-distance connection). The country has compiled a register of benefit codes, which includes more than 20 categories. Students, labour veterans and Chernobyl victims do not have benefits.

In Moldova, compensation has been reimbursed from the state budget through the Ministry of Transport and the Ministry of Social Security to the carrier every month since 2000. Carried out upon presentation of a document certifying the right to benefits (certificate - suburban connection, certificate and coupon - long-distance connection) Benefits established for people with disabilities, war veterans, children and other categories (pensioners) targeted assistance is paid from the state budget along with social benefits. Local administrations establish privileges.

Many countries have already overcome the problems facing the Ukrainian society. At the same time, experts emphasize that the monetization of benefits, as well as other reforms related to the restructuring of the socialist model of management to a market economy and the transition of the Ukrainian economy to the capitalist paradigm, have been introduced in our country for 15-20 years.

The introduction of "monetization" of benefits in the face of a shortage of funds for compensation policy at the regional level had the following consequences:

- significantly increased financial expenditures at all levels of the budget;

- disavowed the main criteria of social policy: address and need;

- the success in carrying out such a large-scale reform and the division of beneficiaries into federal and regional (sometimes within the same family) caused an extremely negative psychological effect;

- only partially solved one of the main tasks of monetization - "to finance the consumer, not the producer".

The conducted analysis allows us to draw the following conclusion - the strategy of support for beneficiaries should work in three directions:

- increase of pensions for gradual reduction of monetary compensations;

- to overcome poverty, the basic principle should be the need to assess income levels; 
- support for the categories that are included in the active process of socialization should be increased fundamentally. Then considerable increases in spending on social needs can be considered more appropriate and effective.

Comparing the international experience of providing transport benefits in the EU and the CIS countries, the advantages and disadvantages are shown in Table 2.

Table 2. International experience in providing transport benefits

\begin{tabular}{|c|c|c|}
\hline & EU countries & CIS countries \\
\hline 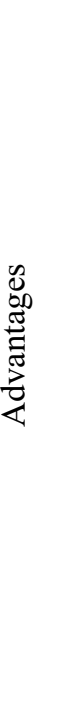 & $\begin{array}{l}\text { travel benefits are } \\
\text { provided through targeted } \\
\text { cash assistance and various } \\
\text { discounts to transport } \\
\text { companies; maximum } \\
\text { minimization of privileged } \\
\text { categories (up to } 5 \% \text { of the } \\
\text { population); for the poor } \\
\text { and the most vulnerable in } \\
\text { the community, the state } \\
\text { provides benefits in the } \\
\text { form of indexation of } \\
\text { salary, tax reduction, etc.; } \\
\text { targeted payments are } \\
\text { mainly made from local } \\
\text { budgets; transportation } \\
\text { benefits are provided at the } \\
\text { regional and local levels }\end{array}$ & $\begin{array}{l}\text { travel benefits are } \\
\text { provided through } \\
\text { targeted cash } \\
\text { assistance; } \\
\quad \text { targeted } \\
\text { payments are made } \\
\text { from the local and } \\
\text { state budgets }\end{array}$ \\
\hline 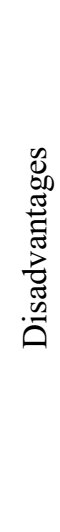 & $\begin{array}{l}\text { not all categories that } \\
\text { need it to receive benefits }\end{array}$ & $\begin{array}{l}\text { the amount of } \\
\text { compensation does } \\
\text { not correspond to } \\
\text { the actual amount of } \\
\text { benefits due to a } \\
\text { large number of } \\
\text { existing privileged } \\
\text { categories; } \\
\text { lack of a flexible } \\
\text { system of payment } \\
\text { of benefits } \\
\text { (compared to EU } \\
\text { countries). }\end{array}$ \\
\hline
\end{tabular}

Passengers depend on the will and mood of the drivers who administer the fare, rather than fulfilling their responsibilities as drivers. Citizens depend on private carriers, which are in fact monopolists on specific city routes. The Ukrainian tariff system does not provide a choice when planning daily, and onetime trips around the city and the choice itself is the basis of economic freedom. Passengers do not have an equal option: to go without a transfer or to use two routes for the same money.

The priority direction of investments is the restoration of the fleet of trams, trolleybuses and buses, which carry out transportation on regular routes. Given the unprofitability of these shipments, it is clear that attracting investment from private entrepreneurs for such purposes is unrealistic.

At present, a plan has been developed to restore the rolling stock to work in the normal mode of traffic at the expense of the carriers. The source of investment of enterprises is a part of the profit from the operation of small-class buses in the route taxi mode.

Given that the compensation of losses from the transportation of privileged categories of passengers and the use of regulated tariffs, as well as investment in the restoration of the fleet of buses of the normal mode of movement, are mainly the only ones.

Due to the inadmissibility of interfering in the economic activities of enterprises, the issue of compensation for losses from the operation of regular buses and investment in their restoration should be one of the conditions for the conduct of competition between competitors.

It is necessary to provide a unified methodological approach to determining the share of each carrier's participation in loss compensation programs and the purchase of buses to operate in the normal mode of operation based on an objective assessment of profits.

Investments in the renewal of the fleet of medium and small class buses, which are used in the mode of a minibus, are expected to be carried out mainly at the expense of enterprises. Given the improvement of the tariff policy, it is also quite real to attract investment funds from private entrepreneurs.

Given the high cost of new rolling stock (especially trams, trolleybuses and buses of large and exceptionally large class) used in urban passenger transport, as well as the relatively long-term return on investment in the development of production and technical base, it is essential for the development of urban transport credit policy. Given that the acquisition of new rolling stock, as a rule, is carried out in the form of leasing or at the expense of credit, companies should have long-term financial relationships with specific financial structures. The conclusion of such agreements will reduce the interest rate on loan and reduce the payback period of fixed assets. Preference is given to the carrier with its own production base, as long as it can be defined as collateral for loans.

The implementation of these measures will significantly improve the quality of passenger transport by urban electric vehicle, increase the fundamental technical and economic indicators of the enterprise, namely:

- increase the number of jobs;

- increase the amount of income from economic activities; 
- to introduce advanced technologies of diagnostics, maintenance and repair of rolling stock of urban transport.

Also, it is necessary to take into account the uneven demand for movement in the direction, speed, price and quality of service. Figure 3. presents the results of the analysis and structuring of demand and its determining factors. Parameters that characterize the offers of UPT services for consumers are presented by four groups: speed of movement, cost, quality of service and direction of movement (Fig. 2.).

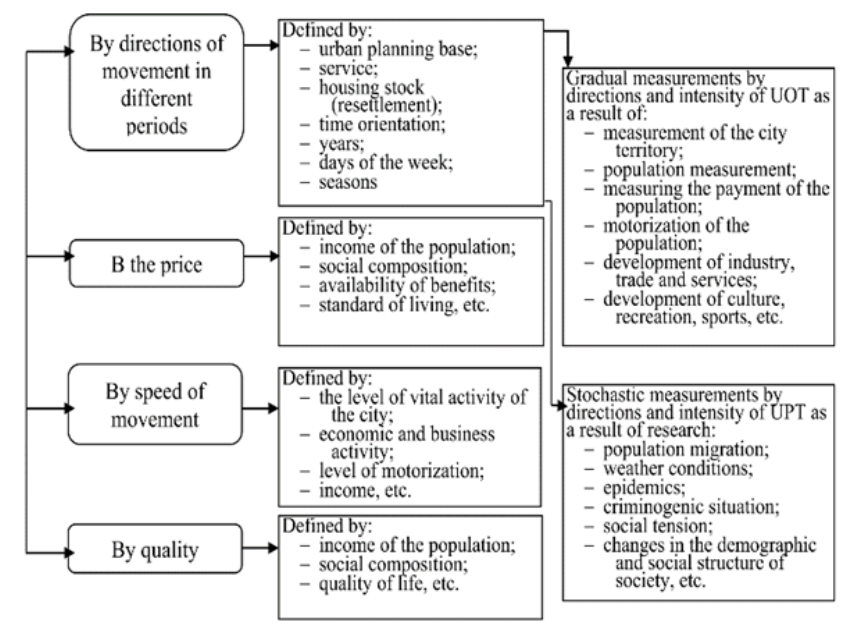

Figure 2. Structure of population demand for UPT services

\section{Results and Discussion}

The basic principle of market organization and the tariff policy in UPT is that costs should be offset by revenues from transportation. Let us represent this expression in relation to the UPT in the form of a diagram, which is shown in Fig. 3.

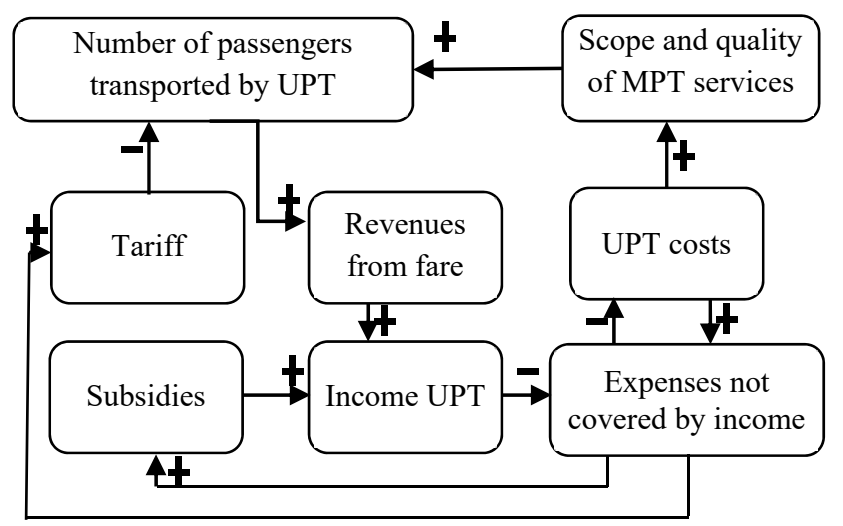

Figure 3. The basic scheme of the organization of the UPT market

The primary tasks of improving the route network are constant monitoring of its condition, identification and refinement of passenger traffic in different directions and its current adjustment taking into account the approach in which each of the directions in the direction. The result is that, in each of the directions, all categories of passengers will be able to meet their own needs in passenger traffic, taking the type of transport (urban electric vehicle, high-class buses, regular, medium and small class buses operating in the minibus), which suits them best in terms of "travel time - comfort - price".

It is implied that in each direction in the obligatory order function as routes of a usual mode of movement (so the minimum cost of travel, transportation of all "privileged" categories of passengers, its lower expenses are higher). (relatively high cost of travel, reduced number of "privileged" passengers, minimum travel time and a higher level of comfort).

The relationship between different modes of traffic, as well as types of rolling stock, is determined based on the study of passenger traffic by categories of passengers because of the advantages they give to a particular kind of transport.

One of the most critical promising measures is the formation, by the current legislation, of a network of routes that will operate at regulated fares and carry out all privileged categories of passengers. Such courses should include all urban-electric transport routes, as well as bus routes operating in normal mode.

The network of routes should be formed in such a way that the pedestrian access (distance from the place of residence or work to the nearest public transport stop) for these routes does not exceed 750 meters [10].

As a promising direction in the development of urban passenger transport, the formation of a highspeed transport axis connecting the "North" and "South" of the city is proposed. The trajectory of the axis should pass through the main passenger-forming points of the city (Paucovtskoho street, Perecypsky Bridge, Sq. Greek, railway station, residential area of Tairova, residential area of Cheremushki, Chernomorka). Along this axis, it is necessary to organize the work of high-speed passenger transport (high-speed tram, light metro, etc.), with the introduction of which the former route network of the city should be reorganized so that some bus routes and urban electric transport routes deliver passengers from the town to the nearest hub transport station. The introduction of high-speed transport will significantly reduce the length of ways, reduce the number of road transport, which will have a positive impact on the environment. Reducing the number of routes will significantly improve the economic and environmental performance of a vehicle.

The effect of route network optimization can be achieved only if the ratio between different types and types of vehicles used on urban routes is optimized. 
At the same time, it is recommended to use part of the profit from the operation of small class buses in the minibus mode, which provides an excess of $15 \%$ profitability, to compensate for losses from the transportation of privileged categories of passengers and use of regulated tariffs in buses conducting an appropriate tariff policy.

At the first stage, in the near future, in order to achieve the above indicators, it is necessary to implement a program of uniform (by years) replacement of small-class buses with a capacity of more than 60 seats.

Current, average and capital repairs of the rolling stock of urban electric transport must be brought to the level provided by the relevant regulations.

Improving the comfort of tram travel was achieved after the modernization of tram cars under the City target program for the development of electric transport in Odessa for 2019-2021, approved by the decision of the Odessa City Council from 20.03.2019 № 4362-VII. The same program provides reduction of operating costs, increase of incomes, reduction of expenses of the electric power, increase of reliability of work of rolling stock, increase in capacity of the tram car, increase in comfort.

From ecological safety, the priority area of work is the re-equipment of urban bus transport for work on gas fuel and, accordingly, the expansion of the network of gas filling stations.

When forming the market of urban passenger transport services, the requirements of significant competition, prevention of market monopolization along with organizational, control and regulatory functions on the part of state and municipal ones must be met.

Within the established route network, the distribution of routes between carriers should be carried out exclusively on a competitive basis, and organizational, technical, economic and other factors that are taken into account when determining the winner of the competition, should be maximally formalized.

Based on the principles of route network formation, the routes to compete should be formed in the form of packages, which include, as a rule, routes of different traffic modes, which mainly work in one direction, with varying levels of rent.

For the efficient distribution of transport in different modes of traffic, it is necessary to systematically survey passenger traffic, taking into account the preferences of passengers in the ratio of "travel time - comfort".
In economic terms, the packages should ensure the profitable operation of the enterprise at a set level of the cost of travel. To ensure this it is necessary to use economic passports of routes. Route packages should be designed in such a way that the average level of their profitability is the same.

A city (municipal) order must be installed for socially significant transportation (in the normal mode of traffic).

The main principles of the city (municipal) order should be:

- the relations of the customer of transportations with the carrier are defined by the contract in which requirements to quality and safety of transportations are stipulated; the fare is fixed, the order of reception of compensation of losses from transportations of privileged categories of passengers and use of regulated tariffs as stipulated;

- the costs of the passenger carrier should not exceed the established standards of the expenses of different types of resources;

- ensuring the interests of the state and the city to perform tasks in the event of emergencies.

The principal investments in urban electric transport at the first stage (except for compensation of losses) should be aimed at the modernization of rolling stock under the City Target Program for the Development of Electric Transport in Odessa for 2019-2021. The volume of these investments should amount to UAH 3,618.48 million for a year. Sources of investment are the city budget, business funds and credit funds (Table 3. and Figure 4.).

Table 3. Sources of investment in the program of development of electric transport of Odessa (developed by the author based on [10].

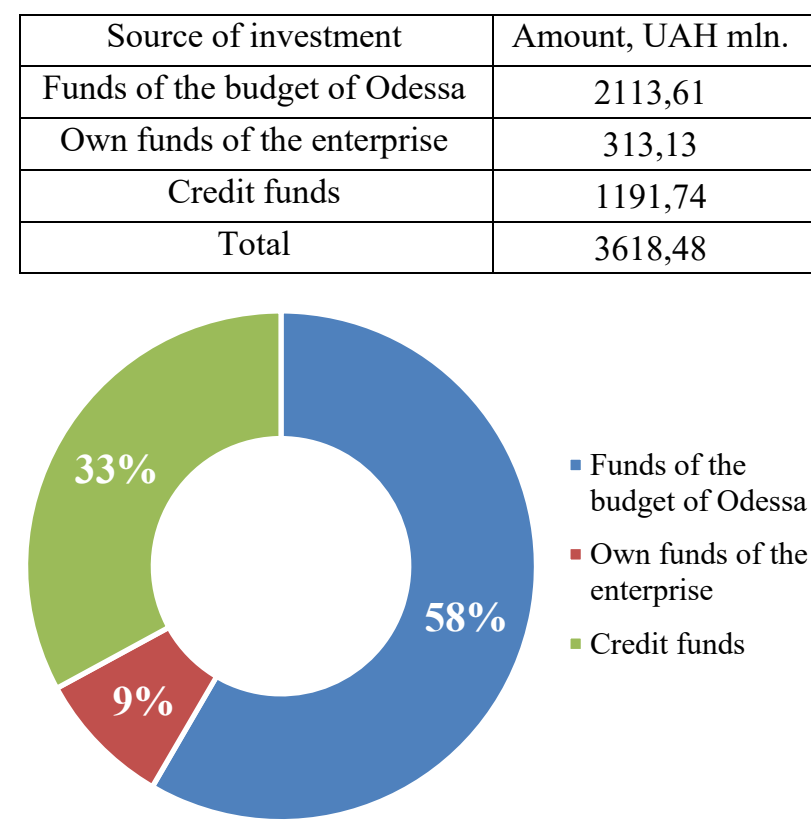

Figure 4. Sources of investment in the program of development of electric transport in Odessa 
Thus, every year in Odessa, the social standards of the quality of passenger transportation are deteriorating on such indicators as the occupancy of vehicles, the provision of urban transport, and motor vehicles. Most trams, subway cars and trolleybuses have been in operation for more than 15 years, and more than half of passenger rail cars for more than 25 years. Public passenger transport enterprises are characterized by unprofitable losses due to the low level of tariffs, insufficient compensation from the budget for the costs of transportation of privileged categories of passengers; inefficiencies of the system of collecting revenues from urban and suburban transit on public passenger transport. Also, in all companies engaged in transportation, there is a shortage of drivers. Severtrans has the most massive deficit - 35\%. However, in developed countries, there is a current and effective tariff and compensation policy for urban passenger transport.

\section{Conclusion}

The study identified the main problems of improving the system of urban passenger transport:

- no dynamics of increasing the number of the rolling stock of electric transport;

- insufficient restoration of the rolling stock of urban electric vehicle, as well as the fleet of large class buses;

- absence of high-speed transport (metro, highspeed tram) in the city;

- lack of automated systems of dispatching control and management

- insufficient development of the city's transport infrastructure (road surface, lighting, automatic traffic control systems) and mechanisms for its financing;

- the inefficiency of the mechanism of management of communal transport enterprises;

- absence of marketing services to study passenger traffic and the factors influencing its change.

Ukraine's transport system has many shortcomings, which need to take into account the strengths and the weaknesses.

\section{Acknowledgements}

The research was supported by Odessa National Polytechnic University and the Ministry of Education and Science of Ukraine (0017U003804).

\section{References}

[1]. Bashynska, I., \& Dyskina, A. (2018). The overviewanalytical document of the international experience of building smart city. Business: Theory and Practice, 19, 228-241.

[2]. Bashynska, I., Kovalova, O., Malovichko, O., \& Shirobokova, O. (2020). Risk Management of Innovative Socially Significant Projects (on the Example of Urban Passenger Transport). International Journal of Advanced Research in Engineering and Technology (IJARET), 11(4).

[3]. Filyppova, S., Okulich-Kazarin, V., Kibik, O., Shamborovskyi, G., \& Cherkasova, S. (2019). Influence of the market of business intellectual services on the innovation safety of EU countries. Journal of Security and Sustainability Issues, 9(1), 347-360.

[4]. Niekrasova, L. \& Bohachenko, M. (2020). Development of all transportation interaction based on integrated tariff-ticket system for passenger transportation. Prychornomorski Ekonomichni Studii, 51, 73-79.

[5]. Oborskiy, G. A., Bundyuk, A. N., \& Tarakhtiy, O. S. (2018). Control system of cogeneration power plant at partial electrical loads. Journal of Automation and Information Sciences, 50(7), 70-78.

[6]. Owais, M., Enieb, M., \& Abbas, Y. A. (2011). Evaluation And Analysis Of Urban Passengers Transport Modes Operation Performance \& Efficiency. Journal of Engineering Sciences, 39(2), 283-299.

[7]. Postnikov, V., \& Pervadchuk, V. (2018). EconomicMathematical Modeling of Suburban Passenger Transport Tariffs. In 5th International Multidisciplinary Scientific Conference on social sciences and arts SGEM 2018 (pp. 235-242).

[8]. Prokopenko, O. V., \& Kas'yanenko, T. V. (2013). Kompleksnyy pidkhid do naukovoho obgruntuvannya ekolohichno spryamovanoho innovatsiynoho rozvytku na riznykh rivnyakh upravlinnya. Aktual'ni problemy ekonomiky, 139(1), 98-105.

[9]. Šipuš, D., \& Abramović, B. (2018). Tariffing in integrated passenger transport systems: A literature review. Promet-Traffic\&Transportation, 30(6), 745751.

[10]. Statistical yearbook of Ukraine for 2018 (2019). State Statistics Service of Ukraine. Retrieved from: http://www.ukrstat.gov.ua/druk/publicat/kat_u/2019/z b/11/zb_yearbook_2018_e.pdf [accessed: 10 May 2020].

[11]. Wiryomartono, B. (2020). Urban Design and Urbanism. In Livability and Sustainability of Urbanism (pp. 101-123). Palgrave Macmillan, Singapore. 